\title{
Spatial and temporal patterns and their influence on fish community at Itupararanga Reservoir, Brazil
}

\author{
Welber Senteio Smith ${ }^{1}$ \& Miguel Petrere Jr. ${ }^{2}$ \\ 1. UNIP/IMAPES/PUC-SP, Rua Antonio Adade, 67 18048-020 Sorocaba, SP. Brazil, e-mail: welber_smith@uol.com.br, \\ Fax: 01515-32215306 \\ 2. Departamento de Ecologia, Universidade Estadual Paulista, CP199, CEP 13506-900- Rio Claro (SP), Brazil
}

\author{
Received 29-I-2008. C Corrected 30-VI-2008. Accepted 31-VII-2008.
}

\begin{abstract}
The Itupararanga Reservoir is located at the Sorocaba River Basin, São Paulo State, Brazil. Five cities use the waters of this reservoir for human consumption. Despite this intensive use of the water resource, no study has been undertaken on the ichthyofauna of this reservoir. Collections were performed in nine sampling stations, where each three were located in the riverine, transitional and lacustrine zones. Fish specimens were collected using eight monofilament gillnets of $10 \mathrm{~m}$ length each, with varied mesh sizes, in the rainy and dry seasons, which corresponded to our spatial scale of analysis. Overall, 14 species of fish were identified, with the highest contribution from Characidae and Curimatidae. The most abundant species were: the "lambari", Astyanax fasciatus, the "saguiru", Cyphocharax modestus, the "lambari bocarra", Oligosarcus paranaensis, and the "mandi", Iheringichthys labrosus. Diversity tended to be higher during the dry season, although the difference was not statistically significant. Cluster analysis identified four season sampling groups differentiated by within-season distribution of species. Mantel's test showed that this distribution was little affected by environmental factors, suggesting that biotic factors were more important in determining the species distribution within the reservoir. Rev. Biol. Trop. 56 (4): 2005-2020. Epub 2008 December 12.
\end{abstract}

Key words: Sorocaba river, Itupararanga Reservoir, structure community, species diversity, species richness, ichtyofauna.

Reservoirs are important artificial ecosystems that modify the hydrological and ecological characteristics of a river (Tundisi 1993) and also cause the highest modifications to the physicochemical characteristics of a hydrographic basin (Agostinho \& Zalewski 1996). These modifications subsequently affect the fish community structure (Godoy 1995). Notwithstanding these negative impacts, reservoirs contribute to the depuration of pollutants (Agostinho \& Zalewski 1996), thereby serving as decantation areas (Petrere \& Agostinho 1993).

Several studies reported the effects of damming on the fish community structure (Fernando \& Holcick, 1991; Beaumord, 1991; Duncan \& Kubecka, 1995). In this regard it is worth mentioning those studies carried out in the reservoirs of the Paraná River Basin, especially at the Tiête River (Castro \& Arcifa 1987; Romanini 1989; Castro 1994; Godoy 1995; Petrere 1996; Agostinho, Bini \& Gomes 1997; Barrella 1998; Smith 1999; Smith \& Petrere 2001; Smith et. al. 2002, Smith et. al., 2003).

Damming, in some cases, can be an insurmountable barrier for any fish species, isolating sites and specific zones that otherwise would be routinely used for feeding or reproduction (Beaumord 1994; Godoy 1995; Agostinho \& Zalewski 1996). This isolation can have a genetic effect on fish populations (Petrere 1985).

A reservoir creates a new, lentic environment, which is expected to impact on the also below remnant community above the dam 
(Beaumord 1991; 1994). This community will suffer modifications related to a decrease in the abundance of some rheophilic species, and a concomitant increase in the number of species with a higher adaptive capacity for lentic environments, such as are the curimatids of the reservoirs of the Parana river basin (Castro \& Arcifa 1987; Rodrigues, et. al. 1990; Barrella 1998; Smith \& Petrere 2001) and Hypophthalmus edentatus and Auchenipterus nuchalis in the Itaipu reservoir (Agostinho et. al. 1994).According to Castro \& Arcifa (1987), Cyphocharax modestus was the most abundant fish species in Sowthern Brazil reservoirs. Agostinho et. al. 1992 verified that before Itaipu damming, Hypophthalmus edentatus and Auchenipterus nuchalis were rare, but just after damming both became responsible for $20 \%$ of the catches.

This happens basically because not all species adapt to this new habitat, so that a reduction in fish diversity occurs. Given this background, the objective of the present work was to describe the fish community of Itupararanga reservoir in terms of its composition, spatial and temporal distribution, diversity and influences of environmental factors.

\section{MATERIALS AND METHODS}

The Itupararanga reservoir is located in the head waters of the Sorocaba river, southeast Brazil. This reservoir receives water from the Sorocabaçu and Sorocamirim rivers, which, in turn, join to form the Sorocaba River (Fig. 1). The reservoir was built in 1912, has a drainage area of $851 \mathrm{~km}^{2}$, a maximum flow of $39.12 \mathrm{~m}^{3} / \mathrm{s}^{-1}$ and a max volume of 286 millions of $\mathrm{m}^{3}$. The power generation capacity is $55 \mathrm{MW}$, and the mean annual production of $150 \mathrm{Gwh}$, is exclusively used by the large Votorantim Corporation. The reservoir is located at the municipality of Votorantim, but it also drains four other municipalities: Ibiúna, Mairinque, Alumínio and Piedade. All these five cities use the water of the reservoir for human consumption.
Samplings were performed in nine sampling stations (Fig. 1), where each three were located in the riverine, transitional and lacustrine zones. Fishes were collected using eight monofilament gillnets of $10 \mathrm{~m}$ length each, with varied mesh sizes (pairs of nets with 30 , 40, 50, 60, 70, 80, 100 and $120 \mathrm{~mm}$ mesh sizes between opposite knots). Samplings were carried out in the rainy (January, February and March 1996) and dry (July and August 1996) seasons, which corresponded to our spatial scale of analysis. Gillnets were set overnight from 18:00 $\mathrm{h}$ to $06: 00 \mathrm{~h}$. The following information necessary for the environmental characterization of the Itupararanga reservoir were collected during sampling: water temperature, $\mathrm{pH}$, transparency, dissolved oxygen, conductivity, presence or absence of the marginal vegetation and macrophyte vegetation, type of bottom (sandy, muddy or rocky) and depth.

Fishes captured were weighed (g), measured in $\mathrm{cm}$ (standard length). The specimens were preserved in formalin $(10 \%)$. Identification was first performed using the identification keys of Britski (1972), Britski et. al. (1984) and later confirmed by Prof. Dr. Heraldo Britski of the Museum of Zoology, University of São Paulo. Voucher specimens were archived in the Museum of Zoology, University of São Paulo.

The following tools were used in studying the different aspects of the fish community: species richness and abundance plots (Magurram 1988), the Shannon-Wiener index of diversity (Magurram 1988) and the Whittaker plots, fit of the data for Log-Series, Lognormal, Geometric and Broken Stick models (Krebs, 1989) and jackknife estimation of species richness (Heltshe \& Forrester 1983). Paired t-tests were used to compare differences in the Shannon-Wiener diversity index (in terms of number and weight) between the rainy and dry seasons. The sampling stations were grouped by their characteristics (water temperature, $\mathrm{pH}$, transparency, dissolved oxygen, conductivity, presence or absence of the marginal vegetation and macrophyte vegetation, type of bottom 


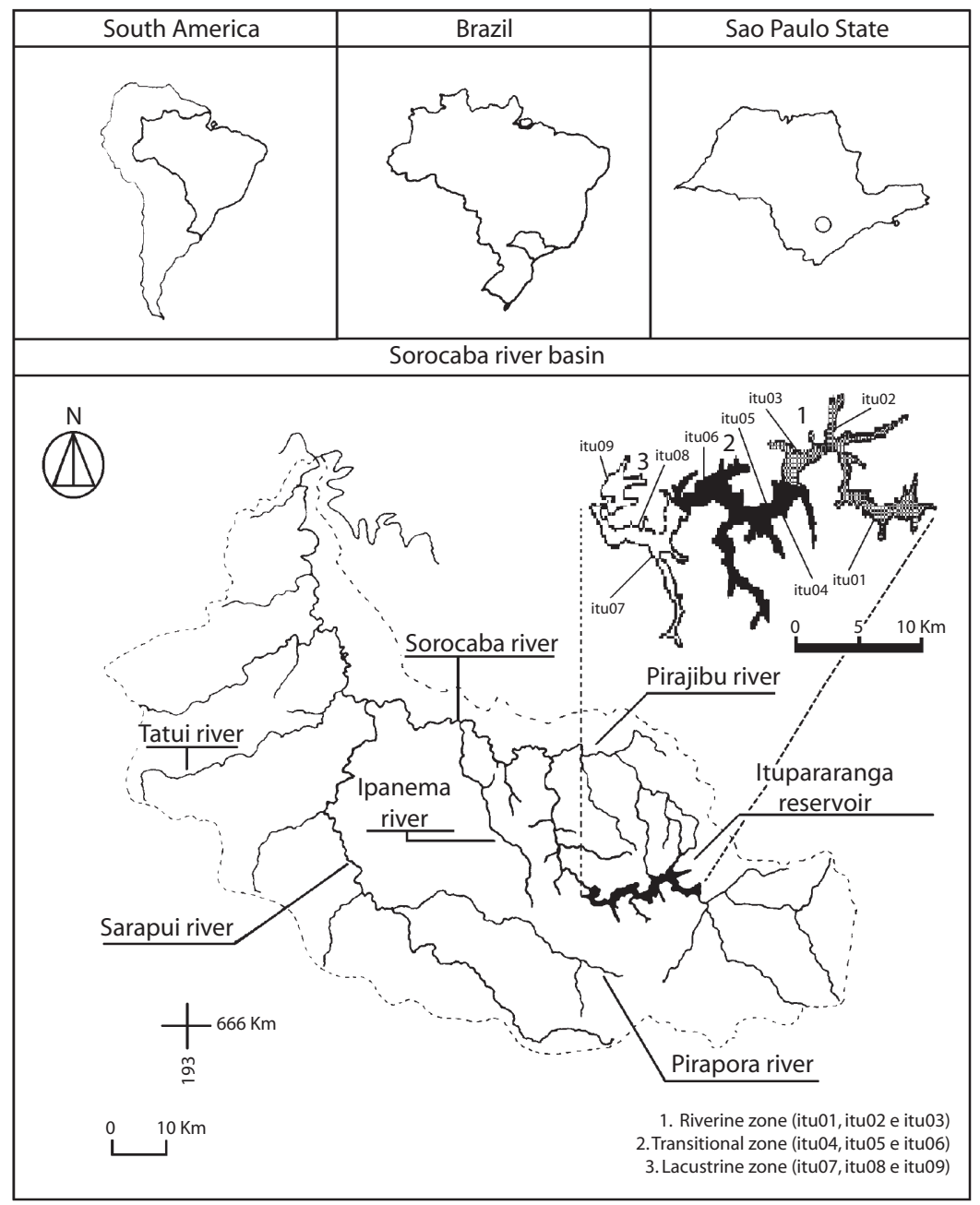

Fig. 1. The Sorocaba River basin, showing the location of the Itupararanga reservoir and the sampling stations.

(sandy, muddy or rocky) and depth) using Euclidian distance, as a metric and unweighted pair group method average (UPGMA) as the clustering method.

The fish species composition among sampling stations and seasons was compared using cluster analysis. Unweighted pair-group method using arithmetic averages (UPGMA) based on Morisita similarity coefficient (Manly 1986; Ludwing \& Reynolds 1988) was used with the numerical abundance data. The cophenetic correlations were calculated for all the dendrograms formed.

The Mantel/pairwise test was used to verify congruence between the similarity matrix (Morisita-Horn) for the abundance of fish species in the reservoir with the matrix (Euclidian distances) for the physical-chemical parameters of the sampling stations (Manly 1986; Ludwing \& Reynolds 1988). Randomization was calculated with 10.000 permutations (Manly 1986; Ludwing \& Reynolds 1988). 


\section{RESULTS}

Environmental characterization of the Itupararanga Reservoir: The abiotic variables for the nine sampling stations in Itupararanga reservoir, during the rainy and the dry seasons, are presented in Table 1. $\mathrm{pH}$ was higher than 7.0 at most stations, during both periods; dissolved oxygen was higher in the rainy season , with the lowest value being found during the dry season. Conductivity was low and oscillated between 51 and $63 \mu \mathrm{S}$, indicating a low concentration of dissolved salts in the water as a consequence of the low dumping of sewage into the reservoir. Overall, the sampling stations showed a small depth, with presence of marginal vegetation. Macrophyte vegetation and transparency, ranged between 0.4-0.5 m were observed for the stations itu01, itu02, itu05 and itu06 during the dry season. The bottom of most of the sampling stations were sandy; except stations itu04 and itu05, which were muddy, while station itu03 was rocky.

A clear distinction in environmental variables was discernible for the sampling stations during the rainy and dry seasons (Fig. 2). In the dry season, the most important variables for the grouping of the stations were those associated with habitat variables such as depth, bottom type and marginal vegetation. However, in the rainy season, physical and chemical variables were responsible for the grouping of the stations, as the within difference in these variables were higher during this season when

TABLE 1

Abiotic variables for 9 sampling stations in the Itupararanga reservoir during the dry (d) and rainy (r) seasons

\begin{tabular}{|c|c|c|c|c|c|c|c|c|c|c|}
\hline Stations & Temp & $\mathrm{pH}$ & Do & Cond & Trans & Mar & Mac & $\mathrm{Sb}$ & $\mathrm{Mb}$ & $\mathrm{Rb}$ \\
\hline Itu01d & 21.2 & 7.4 & 5.8 & 57 & 0.5 & 1 & 0.5 & 1 & 0 & 0 \\
\hline Itu02d & 22.5 & 7.4 & 5.4 & 57 & 1 & 0 & 1 & 1 & 0 & 0 \\
\hline Itu03d & 21.5 & 7.4 & 6.2 & 59 & 0.8 & 0 & 0 & 0 & 0 & 1 \\
\hline Itu04d & 15.6 & 7.2 & 5.6 & 57 & 0.8 & 1 & 0 & 0 & 1 & 0 \\
\hline Itu05d & 17 & 7.4 & 5.7 & 60 & 0.8 & 1 & 1 & 0 & 1 & 0 \\
\hline Itu06d & 18.6 & 7.4 & 6 & 60 & 0.5 & 0.5 & 1 & 1 & 0 & 0 \\
\hline Itu07d & 17 & 7.2 & 5.4 & 58 & 0.3 & 0.5 & 0 & 1 & 0 & 0 \\
\hline Itu08d & 16.2 & 7.2 & 5.8 & 63 & 0.8 & 0.5 & 0 & 1 & 0 & 0 \\
\hline Itu09d & 16 & 7.4 & 5.8 & 58 & 0.5 & 0.5 & 0 & 1 & 0 & 0 \\
\hline Itu01r & 21.5 & 7.33 & 6.68 & 63 & 1 & 0.5 & 0 & 1 & 0 & 0 \\
\hline Itu02r & 21 & 6.97 & 6.45 & 48 & 0.9 & 0.5 & 0 & 1 & 0 & 0 \\
\hline Itu03r & 20.9 & 7.44 & 6.2 & 62 & 4 & 0.5 & 0 & 0 & 0 & 1 \\
\hline Itu04r & 21 & 6.52 & 7.02 & 55 & 0.5 & 0.5 & 0 & 0 & 1 & 0 \\
\hline Itu05r & 21 & 7.5 & 7.9 & 51 & 0.5 & 0.5 & 0 & 0 & 1 & 0 \\
\hline Itu06r & 20 & 7.2 & 7.6 & 52 & 0.6 & 0.5 & 0 & 1 & 0 & 0 \\
\hline Itu07r & 26 & 7.2 & 7.5 & 60 & 0.5 & 0.5 & 0 & 1 & 0 & 0 \\
\hline Itu08r & 25 & 7.4 & 7.3 & 62 & 0.4 & 0.5 & 0 & 1 & 0 & 0 \\
\hline Itu09r & 20.2 & 7.2 & 7.2 & 59 & 0.3 & 0.5 & 0 & 1 & 0 & 0 \\
\hline
\end{tabular}

Temp $\left({ }^{\circ} \mathrm{C}\right)=$ temperature; Do $(\mathrm{mg} / \mathrm{l})=$ dissolved oxygen; Cond $\left(\mu \mathrm{S} . \mathrm{cm}^{-1}\right)=$ conductivity; Trans $(\mathrm{m})=$ transparency; Mar= marginal vegetation $(0=$ absence, $0,5=50 \%$ cover, $1,0=75 \%-100 \%$ cover $)$; Mac $=$ macrophyte vegetation $(0=$ absence, $0,5=$ $50 \%$ cover, $1,0=75 \%-100 \%$ cover $) ; \mathrm{Sb}=$ sandy bottom $(0=$ absence, $1=$ present $) ; \mathrm{Mb}=$ muddy bottom $(0=$ absence, $1=$ present $) ; \mathrm{Rb}=$ rocky bottom $(0=$ absence, $1=$ present $)$; De $(\mathrm{m})=$ depth. 


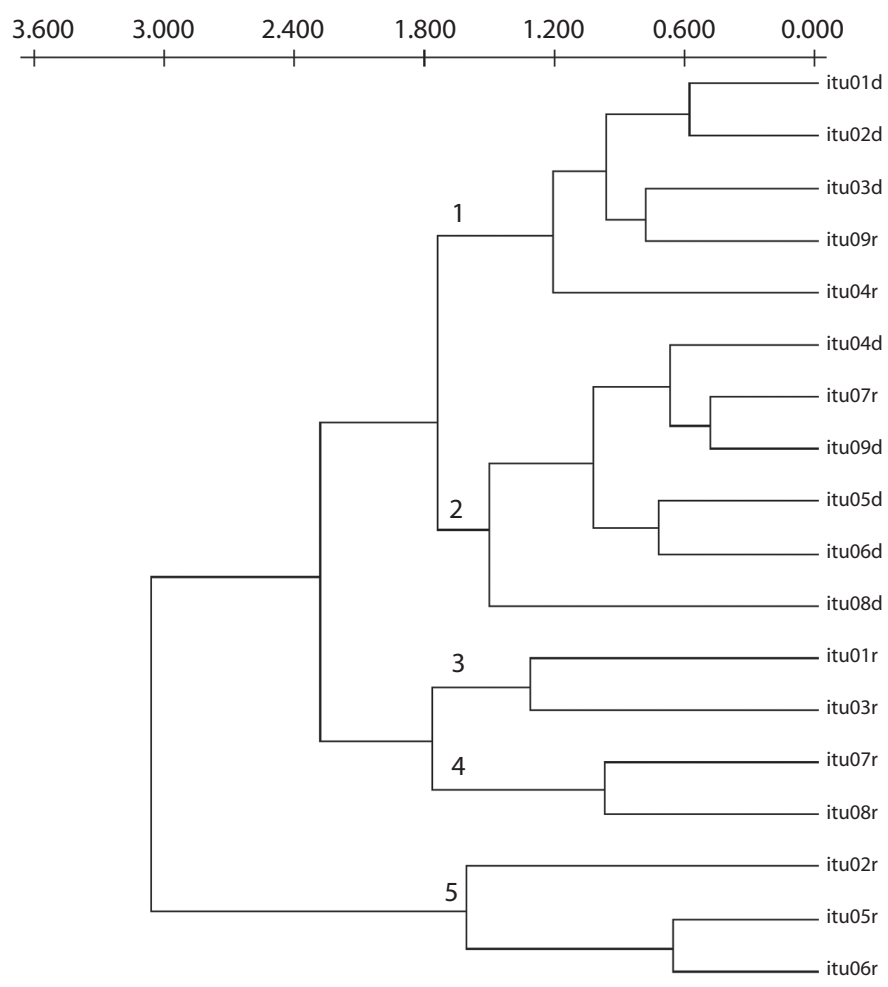

Fig. 2. Grouping of the sampling stations in the Itupararanga reservoir by abiotic variables, during the dry (d) and wet seasons (r). The cophenetic correlation coefficient obtained was $\mathrm{r}=0.81$.

compared to the values observed for the dry season. This differentiation might be related to the rains (summer), which modified the physical and chemical characteristics of the water by increasing the input of sediments and other compounds into the reservoir via the effluents.

The sampling stations were separated into five groups based on physico-chemical parameters. Group 1was comprised by the stations itu01d, itu02d, itu03d, itu09r and itu04r, and is characterized by a low depth, low conductivity and low transparency. Group 2 was comprised by the stations itu04d, itu07d, itu09d, itu05d, itu06 $\mathrm{d}$ and itu08d and was characterized by the lowest values of temperature and dissolved oxygen and the highest $\mathrm{pH}$ values. These were the stations with a sandy or muddy bottom, a depth of around $1.5-2 \mathrm{~m}$, and where samplings were carried out in the dry season. Groups 3 and 4 were composed of the stations itu01r, itu03r and itu07r, itu08r, respectively. They were characterized by higher values of conductivity and transparency as compared to the other groups. These stations were deeper and diverged from each other with respect to the bottom type. Finally, group 5 comprised the stations itu02r, itu05r and itu06r, and was characterized by the highest level of dissolved oxygen among all the groups, low values of conductivity and high depths. This group also contained stations sampled during the wet season (Fig. 2).

Ichthyofauna: richness and species abundance: Eight hundred and seventy two fish specimens belonging to 14 species from 9 families and 4 orders were collected. The family Characidae, mostly Astyanax fasciatus (Cuvier) represented $50 \%$ of the catch. Another important family in the reservoir, 
mostly represented by Cyphocharax modestus (Steindachner), was the Curimatidae, with $19.4 \%$ of the captures (Table 2). The most abundant species in the total sampling were Astyanax fasciatus, Cyphocharax modestus, Oligosarcus paranensis (Menezes \& Géry) and Iheringichthys labrosus (Kroeyer), with 313, 169, 115 and 110 individuals each (Table 2).

The species abundance curve (Whittaker plot), depicting the species richness and abundance in a decreasing order of importance (Fig. 3). Showed Astynax fasciatus, Cyphocharax modestus, Oligosarcus paranensis, Iheringichthys labrosus and Geophagus brasiliensis were the most abundant species, with certain uniformity in abundance distribution, existing among them. In comparing Fig. 3 with theoretical curves (Krebs 1989; Margurram 1988) it was not possible to decide which model best fits the data for this community. Only the Log-Series $(\alpha=2.24 ; x=0.9977$; $\left.\mathrm{x}^{2}=5.839<\mathrm{x}_{0.05 ; 8}^{2}=15.51\right)$ and Lognormal models (median $=0.9869 ; \mathrm{s}^{2}=1.19 ; \mathrm{S}^{*}=15.9$; $\left.\mathrm{x}^{2}=10.21<\mathrm{x}_{0.05 ; 6}=12.59\right)$ fitted the data for the Itupararanga reservoir, while it was not possible to adjust the data with the geometric and the Broken Stick models.

In relation to the mean weight of the individuals, Rhamdia quelen (Quoy \& Gaymard) ( $286.7 \mathrm{~g}$ ), Hoplias malabaricus (Bloch) (253.7 g) and Hoplosternum litoralle (Hancok) (100 g) were the heaviest fishes sampled from the reservoir. On the other hand, Hypostomus ancistroides (Ihering) and Sternopygus macrurus (Bloch \& Schneider), registered the lowest mean of $7 \mathrm{~g}$ each. In terms of length, Gymnotus carapo (Linnaeus) $(30 \mathrm{~cm})$, Rhamdia quelen $(27.2 \mathrm{~cm})$ and Hoplias malabaricus $(23.13 \mathrm{~cm})$ registered the highest mean standard length, while Tilapia rendalli (Linnaeus) $(6.8 \mathrm{~cm})$, Hypostomus ancistroides and Sternopygus macrurus (both $7.7 \mathrm{~cm}$ ) registered the lowest mean standard length (Table 2).

TABLE 2

Abundance, total weight ( $g$ ), mean weight ( $g$ ), and mean standard length (cm) of the species collected at the Itupararanga reservoir

\begin{tabular}{|c|c|c|c|c|c|c|c|}
\hline Species & Code & Abundance & Percentage & Authorities & $\begin{array}{c}\text { Total } \\
\text { weight }\end{array}$ & $\begin{array}{l}\text { Mean } \\
\text { weight }\end{array}$ & $\begin{array}{c}\text { Mean } \\
\text { standard length }\end{array}$ \\
\hline Hoplias malabaricus & $\mathrm{sp} 01$ & 14 & $1,61 \%$ & Bloch & 3805 & 271.8 & 24.8 \\
\hline Astyanax fasciatus & $\mathrm{sp} 02$ & 313 & $36 \%$ & Cuvier & 2377 & 29.7 & 13.2 \\
\hline Gymnotus carapo & $\mathrm{sp} 03$ & 1 & $0,11 \%$ & Linnaeus & 25 & 25 & 30 \\
\hline Hoplosternum litoralle & sp04 & 1 & $0,11 \%$ & Hancock & 100 & 100 & 15 \\
\hline Acestrorhynchus lacustris & $\mathrm{sp} 05$ & 11 & $1,26 \%$ & Reinhardt & 200 & 25 & 30 \\
\hline Tilapia rendalli & sp06 & 2 & $0,23 \%$ & Linnaeus & 15 & 7.6 & 6.8 \\
\hline Geophagus brasiliensis & $\mathrm{sp} 07$ & 99 & $11,36 \%$ & Quoy \& Gainard & 685 & 100 & 15 \\
\hline Rhamdia quelen & sp08 & 3 & $0,34 \%$ & Quoy \& Gainard & 860 & 286.7 & 27.2 \\
\hline Pimelodus maculatus & sp09 & 3 & $0,34 \%$ & Pacépèd & 50 & 16.7 & 13.6 \\
\hline Iheringichthys labrosus & sp10 & 110 & $12,6 \%$ & Kroeyer & 3460 & 31.5 & 13.4 \\
\hline Cyphocharax modestus & sp11 & 169 & $19,4 \%$ & Steidachner & 6303 & 37.3 & 12.7 \\
\hline Hypostomus ancistroides & $\mathrm{sp} 12$ & 25 & $2,87 \%$ & Ihering & 742 & 7,0 & 7.7 \\
\hline Oligosarcus paranensis & sp13 & 115 & $13,2 \%$ & Menezes \& Géry & 2173 & 18.2 & 10.8 \\
\hline Sternopygus macrurus & sp14 & 5 & $0,57 \%$ & Bloch \& Schneider & 35 & 7.0 & 7.7 \\
\hline TOTAL & & 871 & $100 \%$ & & 20830 & & \\
\hline
\end{tabular}




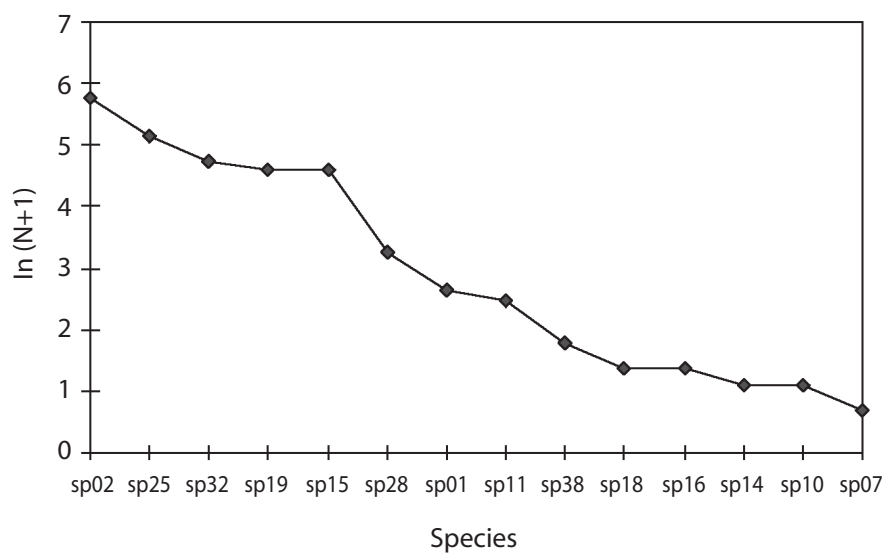

Fig. 3. Whittaker plot for the total collection of fish sampled at the Itupararanga reservoir.

Spatial and Temporal Patterns of the Fish Community and the Influence of Environmental Factors: The higher richness was detected in the riverine zone, when compared with transitional and lacustrine (Table 3). In the dry season, fish were more abundant in the transitional and riverine zones. In the other hand in the high water season fish were less abundant in the riverine zone. In conclusion the higher abundance in the transitional zone is due to the higher dominance of Astyanax fasciatus, Iheringichthys labrosus and Geophagus brasiliensis. These species also occur in the riverine zone together with Cyphocharax modestus and Oligosarcus paranensis. In this zone the numerical abundance of fish was more even.

The spatial distribution of the species (Fig. 4) indicated that Hoplias malabaricus, Astyanax fasciatus, Cyphocharax modestus, Oligosarcus paranensis, Geophagus brasiliensis and Iheringichthys labrosus were widespread throughout the reservoir. Among them, only Iheringichthys labrosus and Hypostomus ancistroides inhabited areas with flowing waters, while most of the other species were typical of lentic habitats. Iheringichthys labrosus, Rhamdia quelen. and Sternopygus macrurus were mostly captured in the main channel of the reservoir, while Hoplias malabaricus, Astyanax fasciatus, Geophagus brasiliensis and Hypostomus ancistroides were captured in greatest numbers in the arms of the reservoir.

Stations itu01, itu02, itu06, itu07, itu08 and itu09 had a sandy bottom; stations itu04 and itu 05 had a muddy bottom and station itu03 a rocky bottom. High rates of capture occurred in stations with sandy bottom, which was the predominant type in the reservoir. Moreover, in the arms of the reservoir there was the highest concentration of marginal vegetation, thus providing a high number of shelters and feeding places.

A cluster analysis carried out in the abundance matrix of the species in the sampling stations, during the dry and wet seasons, discriminated 4 distincts groups due to the differences in numerical abundance of fish species (Fig. 5). Group 1 being formed by the stations itu01, itu02 and itu04 in the dry season. Were characterized by a high abundance of Astyanax fasciatus and Oligosarcus paranensis, suggesting either the utilization of the same resource by either species or a predator-prey relationship.

Goup 2 was comprised the stations itu05 and itu06 in the dry season, and of the station itu01 in the wet season. A high abundance of Cyphocharax modestus and Oligosarcus paranensis was observed for this group. Again this pattern could be due to a predator-prey 
TABLE 3

Abundance of fish species captured per station and per season

Season

Sampling station

Characiformes

Erythrinidae

Hoplias malabaricus

Characidae

Astyanax fasciatus

Acestrorhynchus lacustris

Oligosarcus paranensis

Curimatidae

Cyphocharax modestus

Siluriformes

Loricaridae

Hypostomus ancistroides

Pimelodidae

Pimelodus maculatus

Iheringichthys labrosus

Rhamdia quelen

Gymnotiformes

Gymnotidae

Gymnotus carapo

Sternopygidae

Sternopygus macrurus

Callichthydae

Hoplosternum litoralle

Perciformes

Geophagus brasiliensis

Tilapia rendalli

Total
Dry itu

$\begin{array}{llllllllllllllllll}01 & 02 & 03 & 04 & 05 & 06 & 07 & 08 & 09 & 01 & 02 & 03 & 04 & 05 & 06 & 07 & 08 & 09\end{array}$

$\begin{array}{lllllllllllllllllllllll}1 & 1 & & & 1 & 1 & & 1 & 1 & 2 & & & & 3 & & 1 & & 3 \\ 11 & 10 & 14 & 21 & 7 & 15 & 3 & 1 & 2 & 3 & & 17 & 100 & & 1 & 27 & 25 & 29 \\ 9 & 3 & 10 & 9 & 8 & 30 & & 1 & & 5 & 1 & 2 & 7 & 8 & 5 & 12 & 3 & 2 \\ 5 & 44 & 8 & 8 & 12 & 19 & 6 & 6 & 10 & 5 & 8 & & 24 & 2 & & & 3 & 9\end{array}$

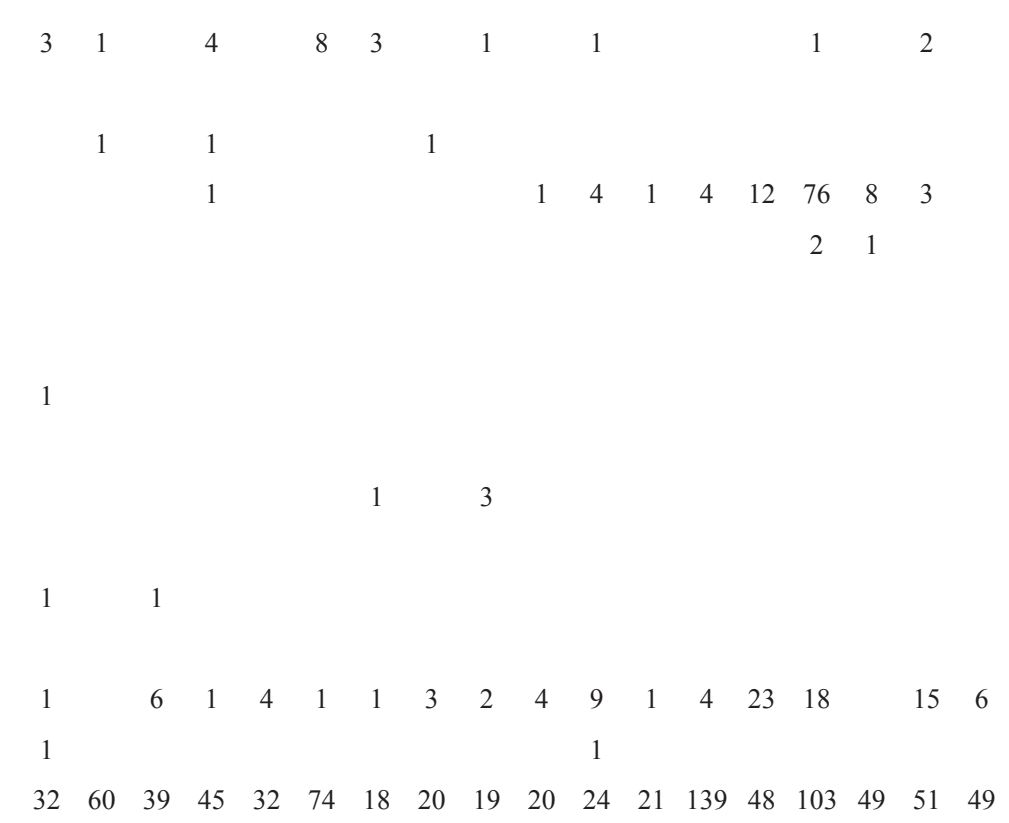

relationship or, by a resource partitioning 4, compried stations itu02, itu07, itu08 and mechanisms acting to avoid competition for shelter. itu09 in the dry season, and itu02 in the wet season, had a high abundance of Astyanax

Group 3, compried the stations itu03, itu04, itu05, itu07, itu08 and itu09 in the wet season, had a high abundance of Astyanax fasciatus, Oligosarcus paranensis, Geophagus brasiliensis and Iheringichthys labrosus. Group fasciatus, Cyphocharax modestus, Gymnotus carapo and Acestrorhynchus lacustris. Station itu06, during the wet season, was separated from the other groups as it showed a different pattern, with a high abundance of the predator 

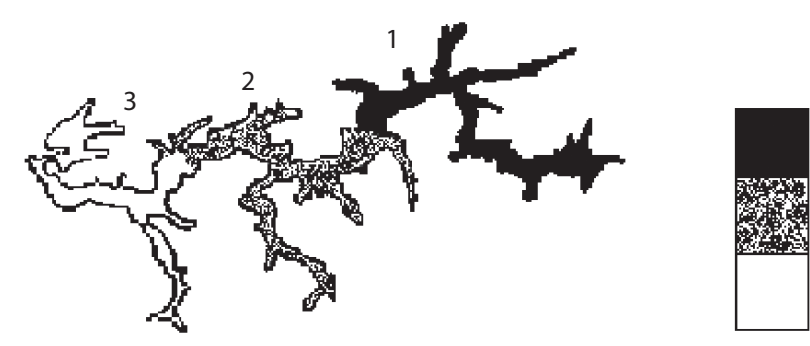

sp01, sp02, sp03, sp04, sp06 sp07, sp09, sp10, sp11, sp12 sp13

sp01, sp02, sp07, sp08, sp 10 sp11, sp12, sp13

sp01, sp02, sp02, sp07, sp09 sp11, sp12, sp13, sp14

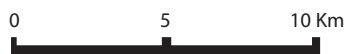

1. Riverine zone

2. Transitional zone

3. Lacustrine zone

\begin{tabular}{|ll} 
Hoplias malabaricus & $\mathrm{sp} 01$ \\
Astyanax fasciatus & $\mathrm{sp02}$ \\
Gymnotus carapo & $\mathrm{sp03}$ \\
Hoplosternum litoraile & $\mathrm{sp} 04$ \\
Acestrorhynchus lacustris & $\mathrm{sp} 05$ \\
Tilapia rendalli & $\mathrm{sp} 06$ \\
Geophagus brasiliensis & $\mathrm{sp} 07$ \\
Rhamdia quelen & $\mathrm{sp} 08$ \\
Pimelodus maculatus & $\mathrm{sp} 09$ \\
Iheringichthys labrosus & $\mathrm{sp} 10$ \\
Cyphocharax modestus & $\mathrm{sp} 11$ \\
Hypostomus ancistroides & $\mathrm{sp} 12$ \\
Oligosarcus paranensis & $\mathrm{sp} 13$ \\
Sternopygus macrurus & $\mathrm{sp} 14$
\end{tabular}

Fig. 4. Spatial distribution of fish species in the Itupararanga reservoir.

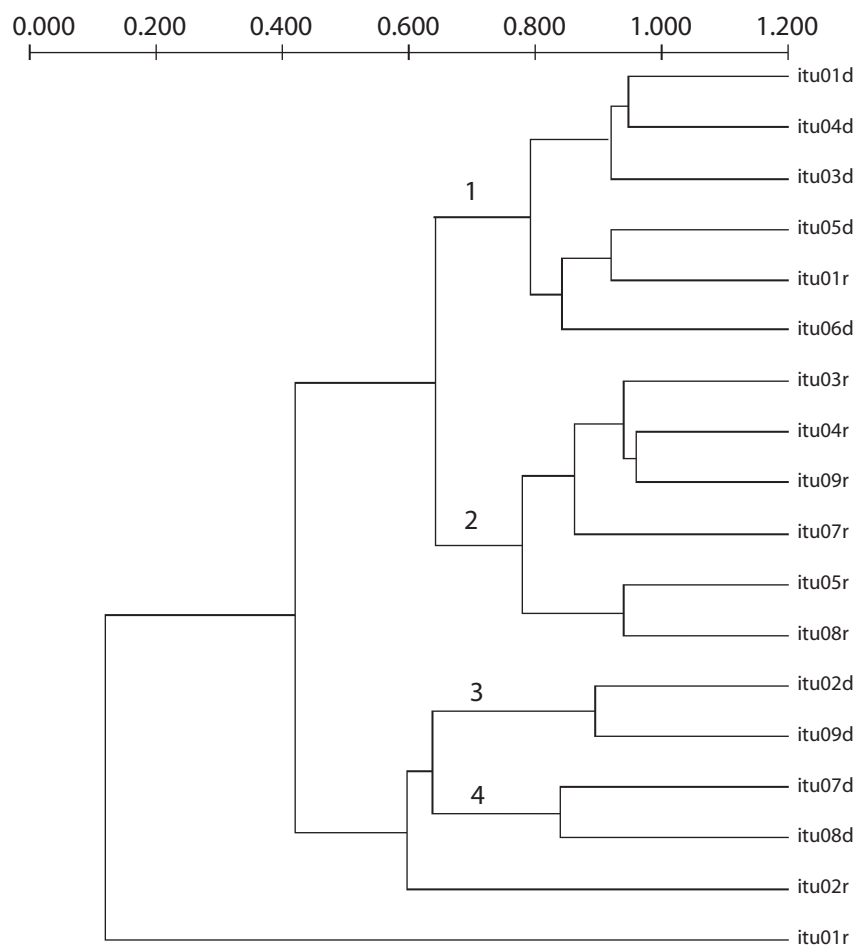

Fig. 5. Dendogram of sampling stations in the Itupararanga reservoir during the dry (d) and wet seasons (r) clustered according to species abundance. The cophenetic correlation coefficient obtained was $r=0.82$. 
species, Iheringichthys labrosus. The Mantel test was used to analyze the effects of abiotic variables on the abundance pattern of the species in the sampling stations. The correlation was significant $(\mathrm{r}=-0.24 ; \mathrm{P}=0.0096)$, the results suggested that abiotic factors had effect on the abundance pattern.

Fish Species Diversity: The ShannonWeiner diversity index for the reservoir was 2.7, while the values for each sampling station (with data from the total abundance) showed seasonal similarity. The highest diversity was found at station itu02 and the lowest at station itu03, with values of 2.57 and 1.97 respectively (Fig. 6). The three stations located on the riverine zone presented higher diversity when compared to the two others.

The diversity calculated for the nine sampling stations during the rainy and dry seasons is shown in Figure 7 (abundance) and Figure 8 (weight). Overall, diversity in abundance was higher during the dry season for most of the stations, although the difference has not statistically significant $\left(\mathrm{t}=1.148\right.$ with $\left.\mathrm{t}_{0.05,8}=2.316\right)$. By comparing the stations with the highest or the lowest diversity with their respective species richness and total abundance for each season, the resulting patterns were the same as observed for the basin as a whole. Stations with the highest diversity also possessed the highest species richness; this correlation was not so strong with respect to total abundance. In the rainy season the lacustrine zone presented higher diversities (itu01 and itu02) while in the dry season diversity was higher in the lacustrine zone stations.

It seems that there was an increase in the weight diversity of the samples close to the dam and those in areas located at the head of the reservoir, indicating higher diversities in weight from the riverine zone down river in both seasons.

Furthermore, a high difference was observed in the biomass diversity among the stations itu03, itu04 and itu06 between the dry and wet seasons. This observation reinforced the seasonal difference in weight diversity, with the highest values being found during the dry season (Fig. 8) although the difference was not statistically significant $\left(\mathrm{t}=2.057 ; \mathrm{t}_{0.05 ; 8}=\right.$ 2.316).

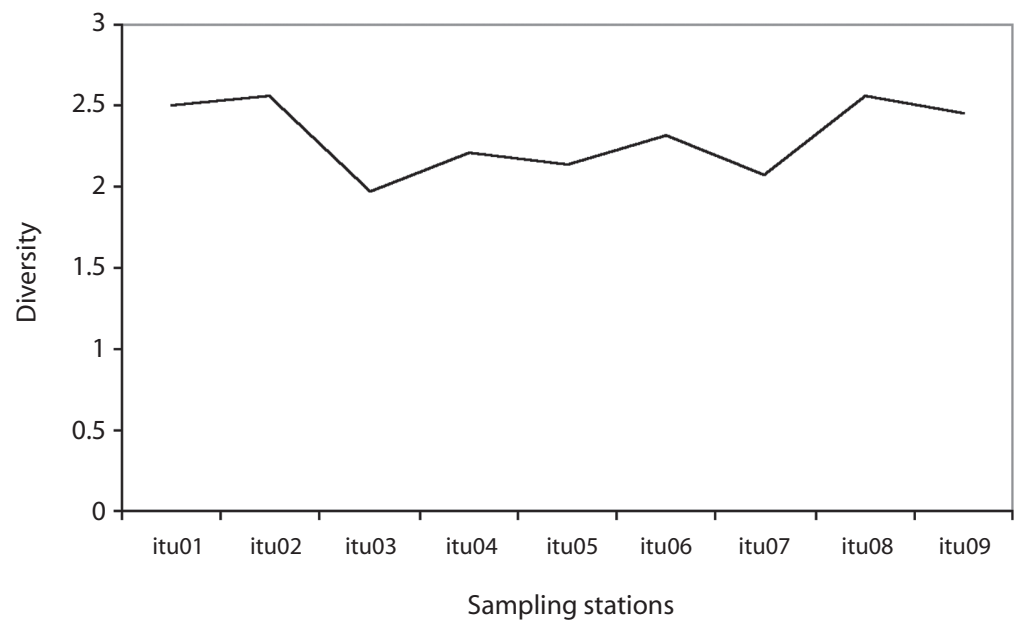

Riverine zone Transitional zone Lacustrine zone

Fig. 6. Shannon diversity index for the Itupararanga Reservoir, using numeric abundance. 


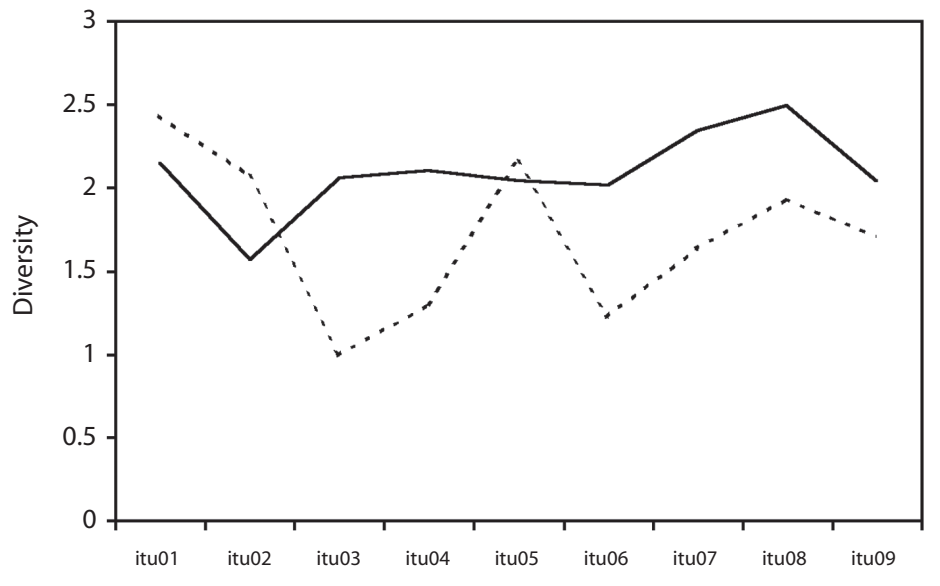

Sampling stations

Riverine zone Transitional zone Lacustrine zone

Fig. 7. Variation in numeric diversity in the sampling stations at the Itupararanga reservoir for the dry (-) and wet (---) seasons.

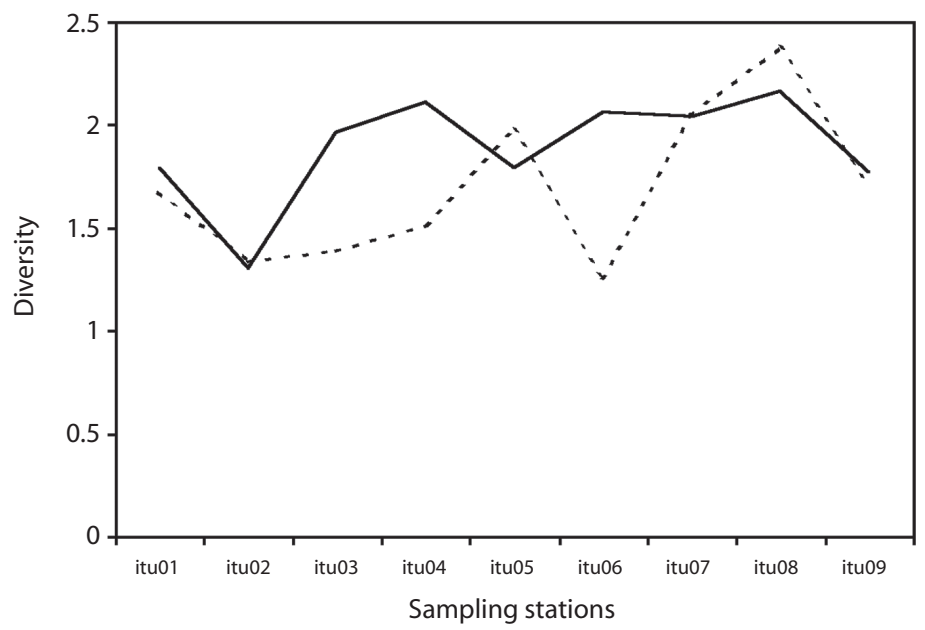

Riverine zone Transitional zone Lacustrine zone

Fig. 8. Variation in the Shannon-Weiner diversity index, calculated from the biomass data, in the sampling stations at the Itupararanga reservoir for the dry $(-)$ and wet (---) seasons. 


\section{DISCUSSION}

The low species richness found in the reservoir might be due to the fact that the area is close to the river head, thus presenting a lower richness and diversity than areas located below. Moreover, a decrease in species richness might have happened in the years following the damn constructions, due to a decrease in habitats suitable for reproduction and initial development of some species (Agostinho et. al. 1997). These hypotheses however, are difficult to corroborate, as there is no study that attempted to follow species richness before and after the dam construction. Another interesting find is the higher richness in the riverine zone, perhaps due the presence in this area of those species also common downriver. This is confirmed by Agostinho et. al. (1999) for the Itaipu reservoir.

Petrere (1996) reported several effects of the damming upon the ichthyofauna, the most important ones being related to the isolation of populations and a decrease in the number of migratory species. Damming, can constitute, in several cases, an insurmountable barrier for any fish species, isolating sites and specific zones of the river where some species normally use for reproduction or as a feeding area (Beaumord 1991; Godoy 1995). This is verified in the Itupararanga reservoir where migratory fish species were rare. By the other hand there is a dominance of Astyanax fasciatus and Cyphocharax modestus, better adapted to lacustrine biotops. These two species are partial spawners, do not care for the eggs and larvae and present high fecundity (Barbieri \& Barbieri 1988; Barbieri \& Hartz 1995). They also utilize with efficiency the local resources in this lacustrine zone.

Castro \& Arcifa (1987) reported that the most abundant and frequent species at several reservoirs in the São Paulo State were Geophagus brasiliensis, Hoplias malabaricus, Astyanax bimaculatus, Astynax fasciatus, Tilapia rendalli and Cyphocharax modestus. This observation was confirmed at the Itupararanga reservoir, where Astynax fasciatus and Cyphocharax modestus were the most frequent species. Besides the higher abundance in the transitional zone of Astyanax fasciatus and Iheringichthys labrosus is due probably the lentics characteristics and the habitat structure favorable to these species. Moreover, we cannot forget the influence of the sampling, therefore the devices of fish can have captured a shoal of fish of each species.

More recent studies at the Barra Bonita (Castro 1994), Promissão (Amaral \& Petrere 1994) and Americana (Romanini 1989) reservoirs also corroborate these results. This similarity was expected, as all these reservoirs are located at the same hydrographic basin. It is noteworthy that, as far as the reservoirs at the Tiête River basin are concerned, the species with the highest level of pre-adaptation to a lentic environment are: Geophagus brasiliensis, Hoplias malabaricus, Astyanax bimaculatus, Astyanax fasciatus, Cyphocharax modestus, Iheringichthys labrosus and Oligosarcus paranensis.

The remnant fish community in the reservoir is derived from the ichtyofauna that already existed in the dammed river (Fernando \& Holcick 1991; Castro \& Arcifa 1987; Agostinho et. al. 1997). Colonization is performed mainly by species pre-adapted to the lacustrine conditions of the new environment. This was clear in the damming stations both at the Sorocaba River and at its affluent. collected in the reservoir creeks basically the some species of the reservoir, as Hoplias malabaricus, Steindachnerina insculpta, Rhamdia quelen, Iheringichthys labrosus and Oligosarcus paranensis, which corroborates what was stated above.

Several factors are responsible for the structuring of fish assemblages in continental aquatic ecosystems (Agostinho et. al. 1997). Physical-chemical factors are also important for structuring the fish community in a reservoir. This factor is directly determined by the operation of the reservoir and can eliminate or decrease the populations that spawn on the border of the reservoir (Castro \& Arcifa 1987). Factors such as seasonality, water volume, 
morphometry, retention time, intra and interspecific interactions and habitat structure can also affect the fish community structure of a reservoir (Agostinho et. al. 1997). Amaral \& Petrere (1994) concluded that environmental factors determined the first scale of the fish community structure at the Promissão reservoir.

Although there were abiotic differences between the sampling stations these were minimal. This seems to contribute to reduce the abiotic variables influences upon fishing communities, stressing the role played by biotic interactions.

The structuring of the fish community at the Itupararanga reservoir seems to be affected by the actual environmental characteristics, such as depth, bottom type, marginal and macrophytes vegetation, as these habitats are important as shelters and feeding areas (Petrere, 1996). These effects are more pronounced in the littoral zone of the reservoir (Fernando \& Holcick 1991), as the abundance distribution in the sampling stations were little affected by the physical-chemical characteristics of the water (as indicated by the Mantel test), even though congruence, albeit small, existed between the abiotic data matrix and the abundance matrix.

The small congruence between the abundance and abiotic matrix might be due to the small number of variables used to characterize the habitats of the reservoir. Thus, a high congruence would have been expected, had we used a large number of different variables to characterize the reservoir.

The cluster analysis, using the environmental variables, clearly separated the sampling stations between the wet and dry seasons. In the dry season, the most important variables were depth, bottom type and marginal vegetation, while during the wet season the physical and chemical variables were responsible for clustering the stations. Thus, in the Itupararanga reservoir, depending on the time of the year, a series of different environmental variables may affect the spatial distribution of the fish community.

Despite the wide distribution of species throughout the reservoir, the abundance is affected by coexistence, an observation supported by the preponderance of different species in different seasons. The cluster analysis of the sampling stations showed that, in stations where Astyanax fasciatus and Cyphocharax modestus were predominant, only one species of predator occured, normally Oligosarcus paranensis. On the other hand, stations with a high abundance of Astyanax fasciatus, Cyphocharax modestus and Geophagus brasiliensis, showed a high number of predators, since the food availability also increased. Accordingly to Matthews (1998), areas with a high number of piscivorous also show a high number of prey. Agostinho et. al. (1997) also confirmed that interspecific interactions, especially predation, were the main processes affecting the distribution and composition of the fish community in a reservoir.

The separation of these groups was based on the abundance data, suggesting the existence of different patterns, which were linked to the habitat structure and biotic relationships. These patterns can be resumed into four types: 1) coexistence between Astyanax fasciatus and Oligosarcus paranensis; 2) coexistence between Cyphocharax modestus and Oligosarcus paranensis; 3) coexistence between Astyanax fasciatus, and Geophagus brasiliensis, associated with other carnivorous species such as Hoplias malabaricus, Oligosarcus paranensis, and Iheringichthys labrosus and 4) coexistence between Astyanax fasciatus and Cyphocharax modestus with other carnivorous species such as Acestrorhynchus lacustris and Sternopygus macrurus.

The coexistence pattern observed at Itupararanga reservoir may be an indication of competitive exclusion (niche segregation) or habitat use, since the Astyanax fasciatus and the Geophagus brasiliensis are omnivorous, feeding on insects, plants and crustaceans. On the other hand, Rhamdia quelen, Iheringichthys labrous, Hoplias malabaricus and Oligosarcus paranensis are carnivorous and Cyphocharax modestus is an illiophagous (Romanini 1989). Analysis of stomach contents is needed to corroborate this hypothesis. Although the 
correlation was significant (Mantel's test), the results suggested that abiotic factors had little effect on the abundance pattern. Thus, in the Itupararanga reservoir, the widespread distribution of the 14 identified species was mostly affected by biotic relationship.

The low diversity in Itupararanga reservoir may related to the high dominance. According to Agostinho et. al. (1999) diversity is higher in the riverine zone, in order to keep the original characteristics of the habitat. Another finding is that diversity is the same in both seasons. This may be explained that seasonal fish migration is negligible. Castro (1997) verified the same result in Barra Bonita reservoir. Gido \& Matthews (2000) suggest that fish assemblages in reservoirs present low temporal variability as its composition is composed by species tolerant to damming consequences, as in Itupararanga.

The Itupararanga reservoir presents homogeneous abiotic characteristics, it is shallow, with low water conductivity, high transparency presenting good drinking water quality. Iits fish fauna is relatively poor, due to its location near to the headstreams. There is a predominance of lentic pre-adapted fish species. It seems that interactions between species play a major role than abiotic factors in order to structure of the fish community. Seasonal variations in fish diversity were not verified.

\section{ACKNOWLEDGMENTS}

We acknowledge the FAPESP (95/13110), FNMA/FUNDUNESP (046/95) and CNPQ for the financial support, Walter Barrella for the comments, Luciano Bonatti Regalado and PUC-SP and CRHEA, USP-São Carlos for the logistic support.

\section{RESUMEN}

El embalse Itupararanga está localizado en la cuenca del río Sorocaba, estado de São Paulo, Brasil, donde cinco ciudades usan sus aguas para consumo humano. A pesar del uso intensivo del recurso agua, ningún estudio se ha llevado a cabo para investigar la ictiofauna de este embalse. Recolectamos los peces en estación seca y lluviosa, en nueve estaciones de muestreo, tres estaciones en cada zona (riverina, transicional y lacustrina). Los peces se recolectaron con ocho atarrayas de un filamento de $10 \mathrm{~m}$ cada una. En total, hallamos 14 especies de peces, con la contribución más alta de Characidae y Curimatidae. Las especies más abundantes fueron: el "lambari", Astyanax fasciatus, el "saguiru", Cyphocharax modestus, el "lambari bocarra", Oligosarcus paranaensis, y el "mandi", Iheringichthys labrosus. La diversidad tendió a ser mayor durante la estación seca, aunque la diferencia no fue estadísticamente significativa. El análisis identificó cuatro grupos de estaciones de muestreo diferenciadas con base en la distribución de especies dentro de cada estación. La prueba de Mantel mostró que esta distribución fue poco afectada por factores ambientales, lo que sugiere que los factores bióticos fueron más importantes al determinar la distribución de especies dentro del embalse.

Palabras clave: río Sorocaba, embalse Itupararanga, estructura de la comunidad, diversidad de especies, riqueza de especies, ictiofauna.

\section{REFERENCES}

Agostinho, A. A., H. F. Júlio Jr. \& J. R. Borghetti. 1992. Considerações sobre os impactos dos represamentos na ictiofauna e medidas para sua atenuação. Um estudo de caso: Reservatório de Itaipu. Rev. Unimar. 14: 89-107.

Agostinho, A. A. \& M. Zalewski. 1996. A planície alagável do alto rio Paraná: importância e preservação. EDUEM, Maringá, Brazil. 100 p.

Agostinho, A. A., H. F. Julio Jr. \& M. Petrere Jr. 1994. Itaipu reservoir (Brazil): impacts of the impoundment on the fish fauna and fisheries, p.161-184. In I.G. Cowx (ed.). Rehabilitation of Freshwaters Fisheries, Oxford Fishing News Books. Oxford, England.

Agostinho, A. A., L. M. Bini \& L. C. Gomes. 1997. Ecologia de comunidades de peixes da área de influência do reservatório de Segredo, p 97-111. In A.A. Agostinho \& L.C. Gomes (eds). Reservatório de Segredo: bases ecológicas para o manejo. Universidade Estadual de Maringá, Brazil.

Agostinho, A. A., L. E. Miranda, L. M. Bini, L. C. Gomes, S. M. Thomaz \& H. L. Suzuki. 1999. Tatterns of Colonization in neotropical reservoirs, and prognoses on aging, p 227-265. In J. G. Tundisi \& M. Straskraba (eds). Theoretical Reservoir Ecology and its Aplications. International Institute of Ecology, Braziliam Academy of Sciences, Brazilia.

Amaral, B. D. \& M. Petrere. 1994. Habitat fatores físicoquímicos relacionados às comunidades de peixes do reservatório da UHE "Mário Lopes Leão-Promissão 
(SP), p 277-293. In I Encontro Brasileiro de Ciências Ambientais, Rio de Janeiro.

Barrella, W. 1998. Alterações das comunidades de peixes nas bacias dos rios Tietê e Paranapanema (SP), devido à poluição e ao represamento. $\mathrm{Ph}$. D. Thesis, UNESP, Rio Claro, Brazil. 115 p.

Barbieri, G. \& M. C. Barbieri. 1988. Curva de maturação, tamanho de primeira maturação gonadal e fecundidade de Astyanax bimaculatus e Astyanax fasciatus da represa do Lobo, Estado de São Paulo (Osteichthyes, Characidae). Rev. Ceres. 35: (197), 64-77.

Barbieri, G. \& S. M. Hartz. 1995. Estudo da fecundidade e tamanho de primeira maturação gonadal de Cyphocharax modestus (Hensel, 1869) da represa do Lobo, Estado de São Paulo (Osteichthyes, Curimatidae). Com. Ciênc. Tecnol. 8: 27-35.

Beaumord, A. C. 1991. As Comunidades de Peixes do Rio Manso, Chapada dos Guimarães, MT: Uma abordagem Ecológica Numérica. Master Dissertation, Rio de Janeiro, UFRJ., Rio, Brazil 107 p.

Beaumord, A. C. \& M. Petrere. 1994. Comunidades de Peces Del Rio Manso, Chapada Dos Guimaraes, MT, Brasil. Acta Bio. Venez, 5: 21-35.

Britski, H. A. 1972. Peixes de água doce de Estado de São Paulo: Sistemática. In: Comissão Interestadual da Bacia Paraná-Uruguai. Poluição e Piscicultura, São Paulo, pp.83-108.

Britski, H.A., Y. Sato \& A. B. S. Rosa. 1984. Manual de identificação de peixes da Bacia do São Francisco - Brasília. Câmara dos Deputados, Coordenação de Publicações-CODEVASF, Divisão de Piscicultura e Pesca. 143 p.

Castro, A. C. L. 1994. Ictiofauna do Reservatório de Barra Bonita-SP: Aspectos ecológicos da Comunidade e Dinâmica populacional da corvina, Plagioscion squamosissimis (Heckel, 1840) (Acanthopterigii, Scianidae). Ph. D. Thesis, Escola de Engenharia de São Carlos, Universidade de São Paulo, São Carlos. $140 \mathrm{p}$.

Castro, R. M. C. \& M. F. Arcifa. 1987. Comunidades de peixes de reservatórios do sul do Brasil. Rev. Bras. Biol. 47 (4): 493-500.

Duncan, A. \& J. Kubecka. 1995. Land/water ecotone effects in reservoirs on the fish fauna.. The importance of aquatic-terrestrial ecotones for freshwater fish. F. Schiemer, M. Zalewski, J.E. Thorpe (eds.). Hidrobiologia. 303:11-30.
Fernando, C. H. \& J. Holcick. 1991. Fish in reservoirs. Int. Revue Ges. Hydrobiol. 76(2): 149-167.

Gido, K. B. \& W. J. Matthews. 2000. Dynamics of the offshore assemblage in a Southwestern reservoir (Lake Texoma, Oklahoma-Texas). Copeia. 4: 917-930.

Godoy, M. P. 1995. Piracema: peixes brasileiros também tem história. Pirassununga-SP, Brasil. Anais de Etologia. 13: 3-19.

Heltshe J. F. \& N. E. Forrester 1983. The jackknife estimate of species richness. Biometrics. 39: 1-11.

Krebs, C. J. 1989. Ecological Methodology. Harper \& Row Publish, New York. 650 p.

Ludwig, J. A \& F. F. Reynolds. 1988. Statistical Ecology. A Primer on Methods and Computing. A Wiley-Interference Publication John Wiley \& Sons. U.S.A. 338 p.

Magurram, A. E. 1988. Ecological disversity and its measurement. Groom Helm London. 90 p.

Manly, B. J. 1986. Multivariate Statistical Methods: A Primer. London, Chapman \& Hall. 281 p.

Matthews, W. J. 1998. Patterns in Freshwater Fish Ecology. Chapman \& Hall. 752 p.

Petrere Jr., M. 1995. A pesca de água doce no Brasil. Ciência Hoje. 110 (19): 28-33.

Petrere, M. 1996. Fisheries in large tropical reservoirs in South America. Lakes \& Reservoirs: Research and Management. 2: 111-133.

Petrere, M. \& A. A. Agostinho. 1993. The Fisheries en the Brazilian Portion of the Paraná River. Consulta de Expertos sobre los Recursos Pesqueros de la Cuenca del Plata, Montevídeo, Uruguay, ONU/FAO/ COPESCAL.

Rodrigues A. M., J. D. Rodrigues, E. C. Campos, A. E. Ferreira \& R. A. Dos Santos. 1990. Aspectos da estrutura populacional do saguirú Curimata gilberti Quoy \& Gaimard, 1824 (Cyphocharax modesta FernandezYepez, 1948) (Characiformes, Curimatidade), na represa de Ponte Nova, rio Tietê, Estado de São Paulo, Brasil. B. Inst. Pesca, São Paulo. 17: 77-89.

Romanini, P. U. 1989. Distribuição e Ecologia Alimentar de peixes no reservatório de Americana, São Paulo. Master Dissertation, São Paulo, USP. 120 p.

Smith, W. S. 1999. A estrutura da comunidade de peixes da bacia do rio Sorocaba em diferentes situações ambientais. Master Dissertation, USP-São Carlos. 121 p. 
Smtih, W. S. \& M. Petrere. 2001. Peixes em represas: o caso de Itupararanga. Rev. Ciência Hoje 29 (170): 74-78.

Smith, W. S., E. L. G. Espíndola, C. C. G. F. Pereira \& O. Rocha. 2002. Impactos dos reservatórios do médio e baixo Tietê (SP) na composição das espécies de peixes e na atividade de pesca, p. 57-72. In Recursos hidroenergéticos: usos, impactos e planejamento integrado, São Carlos, SP. Editora Rima.
Smith, W. S.; C. C. G. F. Pereira \& E. L. G. Espindola. 2003. A importância da zona litoral para disponibilidade de recursos alimentares à comunidade de peixes em reservatórios, p. 233-248. In Raoul Henry (Ed.). Ecotónos nas interfaces dos ecossistemas aquáticos. Editora Rima.

Tundisi, J. G. 1993. Represas do Paraná superior: Limnologia e bases científicas para o gerenciamento, p. 41-52.In A. Boltovskoy \& H.L. Lopez (eds.) Conferencias de Limnologia, La Plata, Argentina. 